\title{
An Accessory Extensor Pollicis Longus Tendon: A Case Report of Rare Anatomical Variant
}

\author{
Tendón Accesorio del Músculo Extensor Largo del Pulgar: \\ Reporte de Caso de una Rara Variación Anatómica
}

\author{
Mohammed H. Karrar Alsharif ${ }^{1,4}$; Mamoun A. Alfaki ${ }^{1,8}$; Abubaker Y. Elamin ${ }^{2,4}$; \\ Elbagir H. Manssor ${ }^{3}$; Khalid M. Taha ${ }^{5}$, Emad M. Arafa ${ }^{6} \&$ Khalid Hadi M. Aldosari $^{7}$
}

ALSHARIF, K. M. H.; ALFAKI, M. A.; ELAMIN, A. Y.; MANSSOR, E. H.; TAHA, K. M.; ARAFA, E. M. \& ALDOSARI, K. H. M. An accessory extensor pollicis longus tendon: A case report of rare anatomical variant. Int. J. Morphol., 35(4):1276-1279, 2017.

SUMMARY: Variation in the morphology of the extensor pollicis longus muscle is very rare. The muscle is considered as one of the deep group of dorsal forearm muscles. It passes through the dorsal radiocarpal ligament in a detached compartment. It inserts at the base of the distal phalanx of the thumb. The muscle might have double tendons where they run either in one, or in separate compartments. In this study, we report an extremely rare condition for a 38 -year-old male where some of the tendon fibers split at the base of the proximal phalanx and the two tendons insert at the sides of the base of the distal phalanx. We also noticed a high range of hyperextension where the action was painless and showed no sign of discomfort. We believe that the way the tendons get inserted might have a role in this wide range of extension.

KEY WORDS: Extensor pollicis longus; Tendon; Interphalangeal joint, hyperextension; Angle of motion.

\section{INTRODUCTION}

In the classic or standard description of extensor pollicis long (EPL) muscle in most of the anatomical references, it is considered with the supinator, abductor pollicis longus, extensor pollicis brevis and extensor indicis proprius as the muscles of deep group of dorsal antibrachial muscles of the forearm (Austin, 2005).

The extensor pollicis longus (also called Extensor secundi internodii pollicis) takes a proximal attachment or origin from the lateral aspect of the middle third of posterior surface of the shaft of ulna (Beatty et al., 2000). The fleshy part, then gets converted into a tendon which is about 6.7 to $9.7 \mathrm{~cm}$. in length (Christ \& Brand-Saberi, 2002). It then passes through dorsal radiocarpal ligament in the detached third compartment (Beatty et al.). The tendon of EPL then forms the posterior boundary of anatomical snuff box. Finally, it passes into the posterior aspect of the base of distal phalanx of thumb (Leaver \& Chatterjee, 2013).
The action of EPL can be easily understood from the tendon insertion that it makes as extension for the thumb at interphalangeal joint at about 100 (Lee \& Jung, 2014). It is the only tendon that can achieve the full hyperextension in this joint (Moore et al., 2010). It shares in the extension of metacarpophalangeal and carpometacarpal joints of the same digit (Austin).

The nerve supply of EPL is by the motor branch of radial nerve i.e. posterior interosseous nerve (or dorsal interosseous nerve) which also supplies to the most of the muscles on the lateral side and posterior aspect of the forearm (Papaloïzos, 2004).

The aim of this work is to highlight the unusual morphology of the distal part of the extensor polices longus muscle, and to test the role that the muscle might play in the range of the thumb movement. The incidence of this variation

\footnotetext{
${ }^{1}$ Anatomy Department, Faculty of Medicine, Prince Sattam Bin Abdulaziz University, Al-Kharj, Saudi Arabia.

${ }^{2}$ Emergency Medical Specialtist Department, Al-Ghad International Colleges for Applied Medical Sciences, Al Madinah Al Munawarah, Saudi Arabia.

${ }^{3}$ Salman bin Abdulaziz University, College of Applied Medical Science, Radiology and Medical Imaging Department, Al-Kharj, Saudi Arabia.

${ }^{4}$ Histology and Embryology Department, College of Medicine, Ondokuz Maiz University, Samsun, Turkey.

${ }^{5}$ Anatomy Department, Faculty of Medicine, University of Science and Technology, Khartoum, Sudan.

${ }^{6}$ Al-Azhar University, Faculty of Medicine, Al-Hussein University Hospital, Cairo, Egypt.

${ }^{7}$ Prince Sattam Bin Abdulaziz University, Faculty of Medicine Al-kharj, KSA.

${ }^{8}$ National University Khartoum Sudan.
} 
is to be discussed because of its great importance in the diagnoses and in medical and surgical reconstruction treatments of hand and wrist diseases such as arthritis at the base of the thumb, de Quervain syndrome, extensor tendons injuries and in many other cases of the same category.

\section{CASE REPORT}

A-38-years old right-handed Sudanese male showed an abnormal painless hyperextension in the interphalangeal (IP) joint of the right-hand thumb. On examination by goniometry (measure the angle of joint) of the thumb, we found out that he can reach about $70^{\circ}$ hyperextension (Fig. 1). While Checking the surface anatomy of the thumb, we noticed that there is an abnormal lateral division in the extensor pollicis longus tendon at the dorsal aspect of the proximal phalanx. Both of the tendons inserted into the sides of the base of the distal phalanx (Fig. 2). Assuming that this might play a role in the range of extension in the interphalangeal (IP) joint up to $70^{\circ}$.

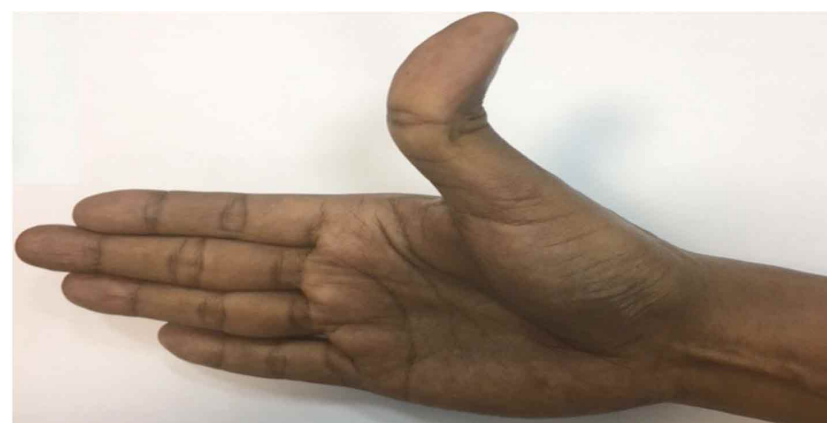

Fig. 1. Range of the hyperextension in the interphalangeal joint of the thumb.

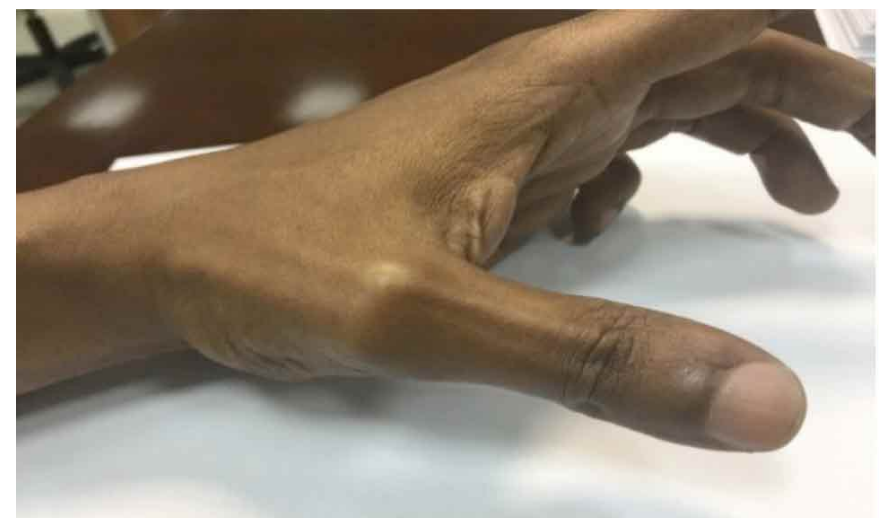

A

Fig. 2. Dorsal aspect of the thumb shows the division from the main EPL muscle which runs laterally.
Multisequence MRI study was conducted after 3plane axial localizer, coronal T1 weighted image, tSE revealed splitting of the pre-insertional portion of Extensor pollicis longus tendon which was seen just distal to the carpometacarpal joint of thumb. Each tendon has its own sheeth. The described splitted tendon appear intact with normal signal void nature, the surrounding osseous and soft tissue structures appear intact (Fig. 3).

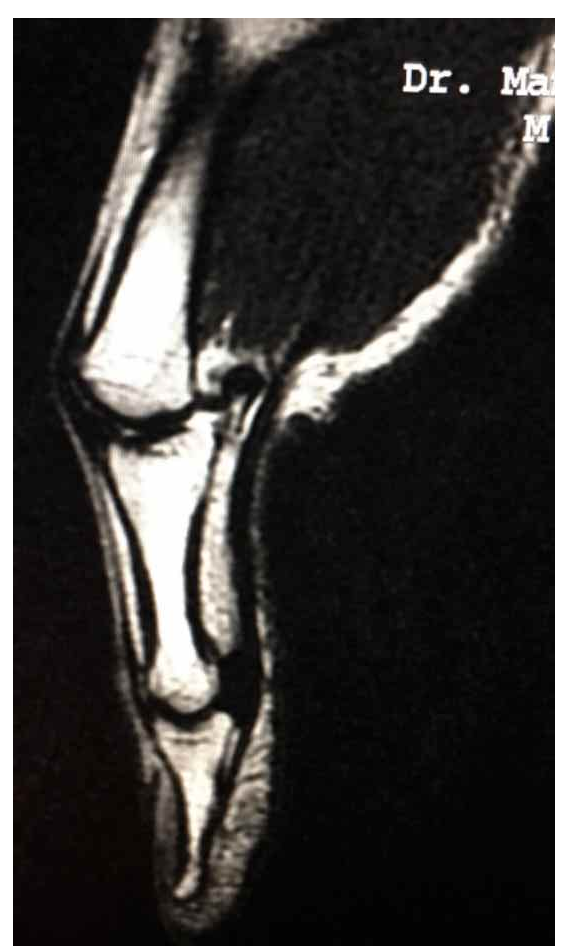

Fig. 3. T1 weighted MRI photograph shows revealed splitting of the pre_insertional portion of extensor pollicis longus tendon.

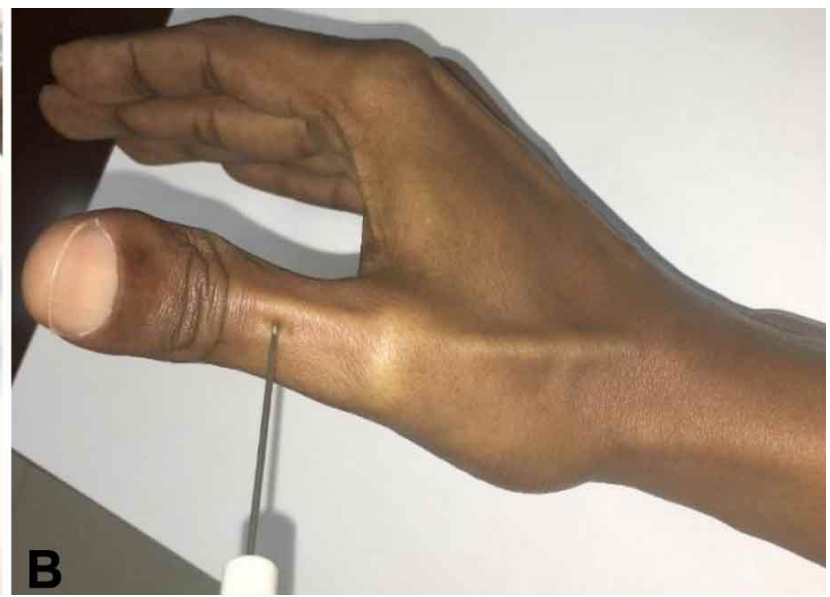



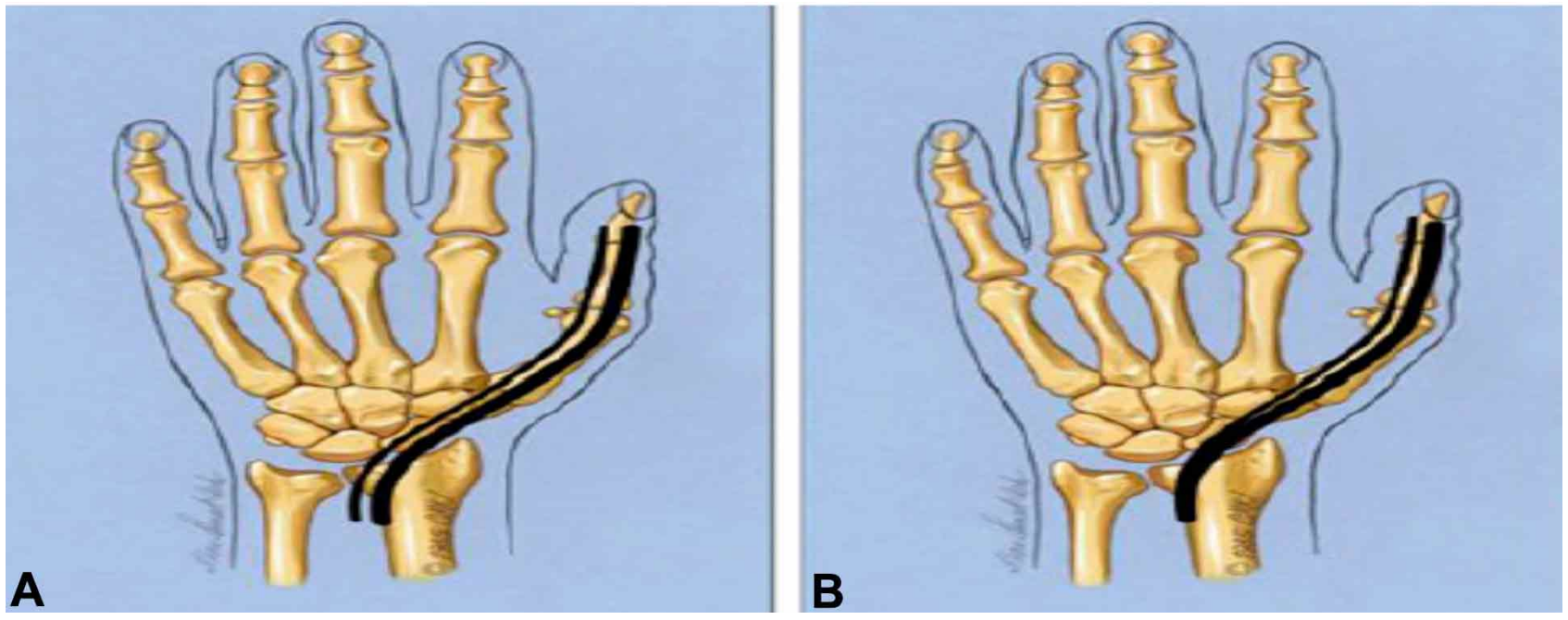

Fig 4. photograph for two anatomical variants for the extensor policis longus (8).

\section{DISCUSSION}

Türker et al. (2010) has categorized a classification system to the anomalies of the extensor policis longus muscle. They mention that the muscle might have double tendons but in a different compartment or double tendons but in the same compartment (Fig. 4).

It has also been reported by Sevivas et al. (2009), that there was a double extensor pollicis longus tendon found in a rheumatoid arthritis patient during a dorsal approach to his wrist. The tendon runs in an additional separate wrist dorsal compartment (Snell, 2012).

This is approved by Beatty et al. who reported a patient who presented with dorsal wrist pain. The investigations showed an accessory extensor pollicis longus muscle which was also found in a third extensor compartment. The pain was resolved following excision of the accessory muscle (Standring, 2008).

Türker et al. added that duplicate extensor pollicis longus tendons might cause inability to extend the thumb at full capacity. This due to an impingement of the musculotendinous junction of the duplicate tendons. They conducted an axial T1-weighted MRI at the level of the distal radioulnar joint which showed two tendons in a third extensor compartment.

In this study, we observed a rare case of the muscle where some of the tendon fibers split. We can also put a hypothesis of proportionality between the angle of motion and number of tendons depending on the side of attachment.

\section{CONCLUSION}

Variation of extensor pollicis longus muscle is a rare anatomical anomaly (Wang \& Weiss, 2013) but knowledge of it, is immense significant because it plays an important role especially during radiological diagnosis and surgical procedures such as reconstructive surgery. Furthermore, it gives us a lot of insight about limb and joint movements. Finally we must keep in mind that hand and thumb tendons variations are usually asymptomatic.

The developmental justification of muscle and/or tendon duplication is due to migration of myoblast into distal of the limb or due to changes that occur in the muscles pattern by the influence of somatopleure mesoderm (Zbrodowski et al., 1982). The division of the tendon of extensor pollicis longus occurs due to signaling from the mesenchymal cells.

ALSHARIF, K. M. H.; ALFAKI, M. A.; ELAMIN, A. Y.; MANSSOR, E. H.; TAHA, K. M.; ARAFA, E. M. \& ALDOSARI, K. H. M. Tendón accesorio del músculo extensor largo del pulgar: reporte de caso de una rara variación anatómica. Int. J. Morphol., 35(4):1276-1279, 2017.

RESUMEN: La variación en la morfología del músculo extensor largo del pulgar es muy rara. Es considerado perteneciente al grupo profundo de los músculos del dorso del antebrazo. Su tendón pasa a través del ligamento radiocarpiano dorsal en un compartimiento separado. Se inserta en la base de la falange distal del pulgar. El músculo puede tener tendones dobles que pasan a través de un solo compartimiento, o en compartimentos separados, del ligamento radiocarpiano dorsal. En este estudio se reporta una variación extremadamente rara en un hombre de 38 años de edad, 
donde algunas de las fibras del tendón se dividen en la base de la falange proximal y los dos tendones se insertaban a los lados de la base de la falange distal del pulgar. También observamos un alto grado de hiperextensión siendo la acción indolora y no mostrando ningún signo de malestar. Creemos que la forma en que los tendones se insertan podrían tener un papel en este amplio rango de extensión.

PALABRAS CLAVE: Músculo extensor largo del pulgar; Tendón; Articulación interfalángica; Hiperextensión; Ángulo de movimiento.

\section{REFERENCES}

Austin, N. M. Chapter 9: The Wrist and Hand Complex. In: Levangie, P. K. \& Norkin, C. C. (Eds.). Joint Structure and Function: A Comprehensive Analysis. $4^{\text {th }}$ ed. Philadelphia, F. A. Davis Company, 2005.

Beatty, J. D.; Remedios, D. \& McCullough, C. J. An accessory extensor tendon of the thumb as a cause of dorsal wrist pain. J. Hand Surg. Br., 25(1):110-1, 2000.

Christ, B. \& Brand-Saberi, B. Limb muscle development. Int. J. Dev. Biol., 46(7):905-14, 2002.

Leaver, H. \& Chatterjee, J. S. Duplicate extensor pollicus longus muscle and tendon-a rare anomaly. Eur. J. Plast. Surg., 36(4):265-6, 2013.

Lee, K. S. \& Jung, M. C. Flexion and extension angles of resting fingers and wrist. Int. J. Occup. Saf. Ergon., 20(1):91-101, 2014.

Moore, K. L.; Dalley, A. F. \& Agur, A. M. R. Clinically Oriented Anatomy. $6^{\text {th }}$ ed. Philadelphia, Wolters Kluwer/Lippincott Williams \& Wilkins, 2010.

Papaloïzos, M. Y. Accessory extensor pollicis longus. Scan. J. Plast. Reconstr. Surg. Hand Surg., 38(5):310-3, 2004.

Sevivas, N.; Kalouche, I. \& Roulot, E. Double extensor pollicis longus tendon in independent extensor compartments: a case report of an anatomical variation requiring alteration of surgical strategy. Chir. Main., 28(3):180-2, 2009.

Snell, R. S. Clinical Anatomy by Regions. $9^{\text {th }}$ ed. Philadelphia, Lippincott Williams \& Wilkins, 2012. pp.334-433.

Standring, S. Gray's Anatomy: The Anatomical Basis of Clinical Practice. $40^{\text {th }}$ ed. Edinburgh, Churchill Livingstone/Elsevier, 2008.

Türker, T.; Robertson, G. A. \& Thirkannad, S. M. A classification system for anomalies of the extensor pollicis longus. Hand (N. Y.), 5(4):403-7, 2010.

Wang, L. H. \& Weiss, M. D. Anatomical, clinical, and electrodiagnostic features of radial neuropathies. Phys. Med. Rehabil. Clin. N. Am., 24(1):33-47, 2013.

Zbrodowski, A.; Gajisin, S. \& Grodecki, J. Vascularization of the tendons of the extensor pollicis longus, extensor carpi radialis longus and extensor carpi radialis brevis muscles. J. Anat., 135(Pt. 2):235-44, 1982.

\author{
Corresponding author: \\ Mohammed Hamid Karrar B. Sc. M.Sc. \\ Lecturer of Anatomy \\ Prince Sattam bin Abdulaziz University \\ Faculty of Medicine \\ Dept. of Basic Medical Science K.S. A. \\ SAUDI ARABIA
}

E-mail:dr.anatomy83@yahoo.com

Received:16-04-2017

Accepted:12-06-2017 